\title{
Post-Variscan thermal history of the Intra-Sudetic Basin (Sudetes, Bohemian Massif) based on apatite fission track analysis
}

\author{
Dariusz Botor $^{1}$ (D) $\cdot$ Aneta A. Anczkiewicz ${ }^{2} \cdot$ Stanisław Mazur $^{2} \cdot$ Tomasz Siwecki $^{2}$
}

Received: 29 September 2018 / Accepted: 30 September 2019 / Published online: 23 October 2019

(c) The Author(s) 2019

\begin{abstract}
The Intra-Sudetic Basin, a $12 \mathrm{~km}$ deep Variscan intramontane basin, has the best preserved post-orogenic sedimentary record available at the NE margin of the Bohemian Massif. Apatite fission track (AFT) analyses have been performed on 16 sedimentary and volcanic samples of Carboniferous to Cretaceous age from the Intra-Sudetic Basin to improve understanding of the post-Variscan thermal evolution. AFT central ages range from $50.1 \pm 8.8$ to $89.1 \pm 7.1 \mathrm{Ma}$ (Early Eocene to Coniacian), with 13 of them being Late Cretaceous. The mean track length values range from $12.5 \pm 0.4$ to $13.8 \pm 0.5$ (except for one sample $14.4 \pm 0.2) \mu \mathrm{m}$. This relatively short mean track length together with the unimodal track length distributions and rather low standard deviation $(0.8$ to $1.7 \mu \mathrm{m})$ in most samples indicate a long stay in the partial annealing zone during slow cooling. However, in the northern part of the Intra-Sudetic Basin, samples show a wider track length distribution (standard deviation of 1.8 to $2.1 \mu \mathrm{m}$ ) that could indicate a more complex thermal evolution possibly related to Mesozoic reheating. Vitrinite reflectance data combined with thermal models based on the AFT results indicate that the Carboniferous strata reached maximum palaeotemperatures in the latest Carboniferous to Early Permian time, corresponding to a major coalification event. The second phase of temperature rise occurred due to Late Mesozoic sedimentary burial, but it had no influence on maturation of the Carboniferous organic matter. Final cooling phase in the Late Cretaceous-Paleogene was related to tectonic inversion of the Intra-Sudetic Basin, which occurred after deposition of a significant thickness of Cenomanian-Turonian sediments. Thermal modelling demonstrates that $\sim 4 \mathrm{~km}$ thick cover of Upper Cretaceous sediments is required to obtain a good match between our AFT data and modelled time-temperature paths. This outcome supports a significant amount of Late Cretaceous-Paleogene inversion within the Variscan belt of Central Europe.
\end{abstract}

Keywords Thermal modelling $\cdot$ Carboniferous $\cdot$ Coalification $\cdot$ Heat flow $\cdot$ Cooling $\cdot$ Tectonic inversion $\cdot$ Mesozoic $\cdot$ Variscides

Dariusz Botor

botor@agh.edu.pl

Aneta A. Anczkiewicz

ndstruzi@cyf-kr.edu.pl

Stanisław Mazur

ndmazur@cyf-kr.edu.pl

Tomasz Siwecki

t.siwecki@ingpan.krakow.pl

1 Faculty of Geology, Geophysics and Environmental Protection, AGH University of Science and Technology, al. Mickiewicza 30, 30-059 Kraków, Poland

2 Institute of Geological Sciences PAS, ul. Senacka 1, 31-002 Kraków, Poland

\section{Introduction}

The low-temperature post-Variscan history of the Sudetes, NE Bohemian Massif (Fig. 1), is still a matter of debate, particularly due to the sparsely preserved post-Variscan geological record (e.g. Maluski et al. 1995; Migoń and Danišík 2012; Danišík et al. 2012; Sobczyk et al. 2015; Botor et al. 2017a, b). Previous low-temperature thermochronological studies, mostly based on apatite fission track (AFT) data, suggest that the Bohemian Massif experienced a complex post-orogenic thermal evolution that may have been influenced by burial under Mesozoic sediments, Late Cretaceous inversion-related exhumation and inception of the European Cenozoic Rift System (Jarmołowicz-Szulc 1984; Wagner et al. 1997; Hejl et al. 1997, 2003; Thomson and Zeh 2000; Glasmacher et al. 2002; Ventura and Lisker 2003; Aramowicz et al. 2006; Ventura 

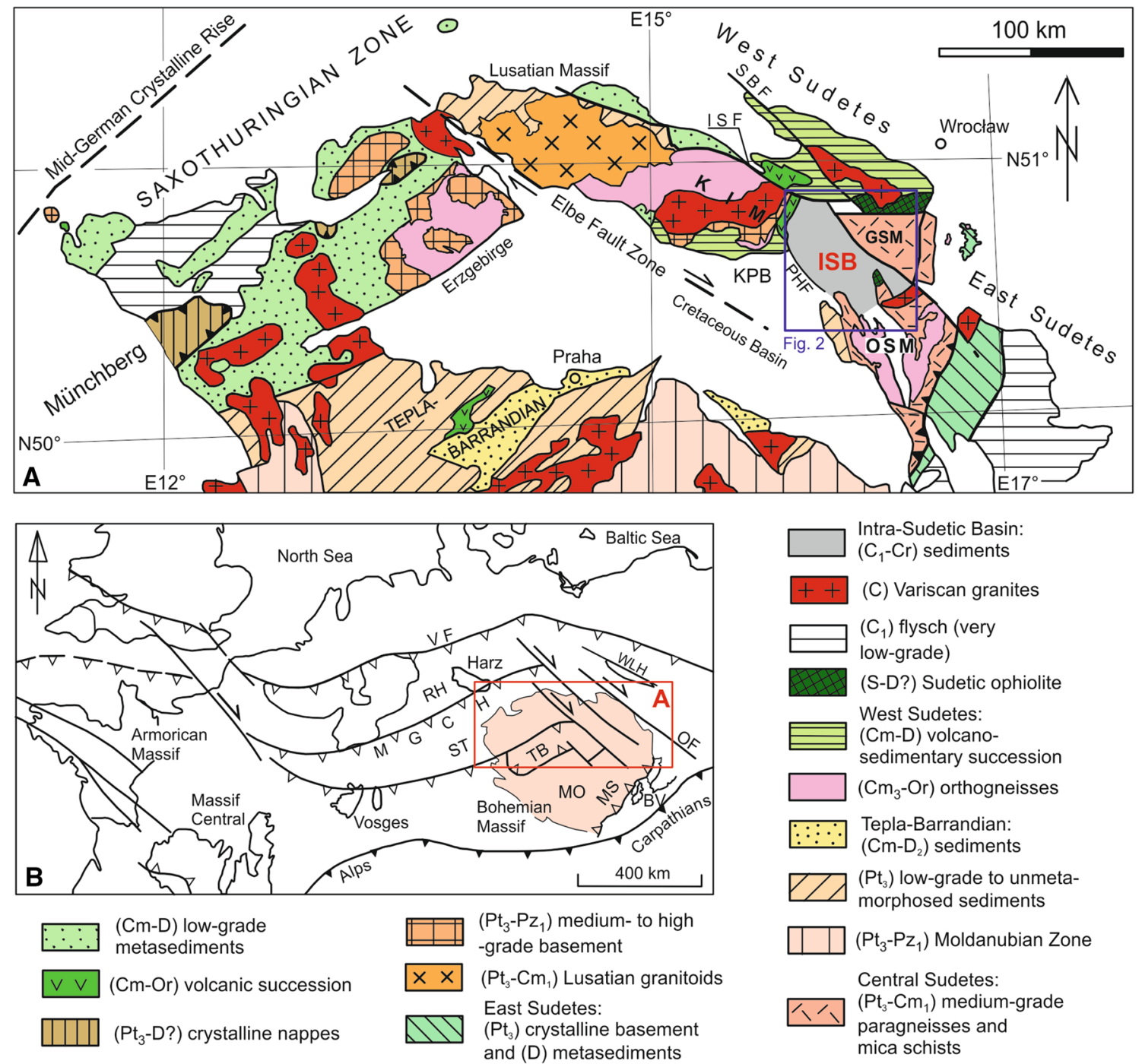

Fig. 1 Tectonic setting of the Intra-Sudetic Basin within the Variscan belt of Europe (modified from Franke et al. 1995). a Geological sketch of the northern part of the Bohemian Massif. b Main tectonic units of the Variscan belt. $B V$ Brunovistulicum, GSM Góry Sowie Massif, ISB Intra-Sudetic Basin, ISF Intra-Sudetic Fault, KIM Karkonosze-Izera Massif, $K P B$ Krkonoše Piedmont Basin, $M G C H$ Mid-German Crystalline High, MO Moldanubian Zone, MS Moravo-

et al. 2009; Vamvaka et al. 2014; Wolff et al. 2015). Moreover, significant sedimentary burial may have caused resetting of zircon (U-Th)/He ages in the central part of the Sudetes during the Late Cretaceous (Danišík et al. 2012; Sobczyk et al. 2015), whereas the stratigraphic record suggests less than $1 \mathrm{~km}$ of Mesozoic sedimentary cover (e.g. Milewicz 1997). The latter inspired a paleogeographic model of postulating islands emerging from a shallow Late Cretaceous sea (e.g. Milewicz 1997). The aim of this study is to improve our understanding of the post-Variscan thermal evolution using AFT thermochronology from the Intra-Sudetic Basin (ISB), a deep intramontane basin having the best post-orogenic sedimentary record
Silesian Zone, $O F$ Odra Fault, $O S M$ Orlica-Śnieżnik Massif, $P H F$ Poříćí-Hronov Fault, $R H$ Rhenohercynian Zone, $S B F$ Sudetic Boundary Fault, $S T$ Saxothuringian Zone, TB Teplá-Barrandien Zone, $V F$ Variscan deformation front, $W L H$ Wolsztyn-Leszno High. Age assignments: $\mathrm{Pt}_{3}$ Late Proterozoic, $\mathrm{Cm}$ Cambrian, $\mathrm{Or}$ Ordovician, $\mathrm{S}$ Silurian, $\mathrm{Pz}_{l}$ Lower Palaeozoic, $\mathrm{D}$ Devonian, $\mathrm{C}$ Carboniferous, $\mathrm{Cr}$ Cretaceous

available in the Sudetes. Low-temperature thermochronological information revealed by the AFT data supplement stratigraphic evidence available in the basin and shed new light on its subsidence history as well as the post-Variscan tectonic evolution of the Bohemian Massif.

\section{Geological setting}

The ISB, situated at the NE flank of the Bohemian Massif, is one of the largest intramontane throughs widespread along the Variscan belt of Europe (Figs. 1, 2; e.g. Awdankiewicz 
1999a; Ulrych et al. 2006; Opluštil and Cleal 2007; Mazur et al. 2007). The ISB constitutes a large fault-bounded synclinorial structure, $70 \mathrm{~km}$ long and $35 \mathrm{~km}$ wide, which extends in the WNW-ESE direction (Fig. 2). The total thickness of the basin fill attains $\sim 12 \mathrm{~km}$. The basin is framed by various crystalline basement units of Variscan age and by other Late Palaeozoic sedimentary basins. The PořícíHronov Fault Zone and the Struga Fault separate the ISB from the Karkonosze Piedmont Basin and the Świebodzice Basin, respectively (Fig. 2; e.g., Porębski 1981; Awdankiewicz 1999a; Ulrych et al. 2004, 2006).

Development of the ISB was initiated in the Mid-Viséan (Turnau et al. 2005; $336 \mathrm{Ma}$ ) as an intramontane depression bounded by tectonically active margins (Teisseyre 1968). The Lower Carboniferous extensive fluvial sequence of the ISB consists of the Middle-Upper Viséan clastic sediments (Turnau et al. 2005; Fig. 3) that are succeeded by the Upper Viséan deposits of a marine transgression (Fig. 3; Żakowa 1963; Teisseyre 1968, 1975). Tectonic uplift at the transition from the Early to Late Carboniferous led to marine regression and accumulation of an Upper Carboniferous continental succession, typical of alluvial environment (Fig. 3; Dziedzic 1971; Dziedzic and Teisseyre 1990; Bossowski and Ihnatowicz 1994). This succession of predominantly coal-bearing character is well known for bituminous and anthracite coal deposits (Kwiecińska 1967; Mastalerz and Jones 1988; Mastalerz and Smyth 1988; Mastalerz and Wilks 1992; Nowak 1993, 1996). The Autunian (lower Permian) sediments of the ISB (Fig. 3) include clastic deposits of alluvial fan, fluvial and lacustrine environments (Dziedzic and Teisseyre 1990). Intense tectonic activity during the Saxonian led to significant uplift of the ISB frames and substantial erosion of its elevated margins (Dziedzic and Teisseyre 1990; Awdankiewicz 2004). The Carboniferous and Permian development of the ISB was associated with three Variscan stages of volcanic/magmatic activity during: (1) Middle Viséan, (2) Late Westphalian and Stephanian and (3) Early Permian, the latter corresponding to a peak of volcanic activity (Awdankiewicz 1999a, b, 2004; Ulrych et al. 2011; Opluštil et al. 2016). The Late Palaeozoic magmatism included widespread volcanic complexes of lavas, shallowlevel intrusions and volcaniclastic deposits interstratified in Permian-Carboniferous sedimentary successions (Awdankiewicz 1999a, 2004; Mazur et al. 2007).

In post-Variscan times, the basin fill succession was overlain by $\sim 100 \mathrm{~m}$ Lower Triassic continental and up to $900 \mathrm{~m}$ (present-day thickness) Upper Cretaceous shallow marine deposits (Figs. 2, 3). Fine-grained sandstones, siltstones, calcrete and gypsum horizons of Late Permian-Early Triassic age are interpreted as an indication for peneplanation of the Variscan basement blocks (Lorenz and Mroczkowski 1978; Malkovský 1987; Feist-Burkhardt et al. 2008). Since the Bohemian Massif formed a large and coherent high between the Middle Triassic and Middle Jurassic (Ziegler and Dèzes 2007), no sediments of the Middle Triassic to Early Cretaceous age are recorded in the ISB. During the Cenomanian, a transgression covered large parts of the Bohemian Massif and a system of rapidly subsiding basins formed along reactivated Variscan shear zones, where a thick succession (up to $\sim 1200 \mathrm{~m}$ ) of shallow marine sediments was deposited (Skoček and Valečka 1983; Uličný 2001; Scheck et al. 2002; Uličný et al. 2009; Wojewoda et al. 2016). In the Late Turonian to Paleocene, the Bohemian Massif was affected by transpressional deformation induced by far-field stresses from the Europe-Africa plate convergence (e.g. Kley and Voigt 2008). This led to reactivation of the NW-SE striking Variscan basement faults within the Elbe Fault System with vertical offsets reaching $4 \mathrm{~km}$ (Scheck et al. 2002; Otto 2003), formation of thrust-related uplifts, erosion of elevated basement blocks and inversion of the Cretaceous basins (Kley and Voigt, 2008). This is evidenced by the deformation of the Cretaceous strata, the abrupt cessation of sedimentation in the Late Cretaceous sedimentary basins and also by a distinct cooling phase recorded by thermochronological data in the western and central parts of the Sudetes (Skoček and Valečka 1983; Jarmołowicz-Szulc 1984; Jarmołowicz-Szulc et al. 2009; Ziegler 1987; Uličný 2001; Aramowicz et al. 2006; Ventura et al. 2009; Danišík et al. 2010; Sobczyk et al. 2015).

Subsequently, the Bohemian Massif was subjected to intense weathering and erosion, resulting in the development of a peneplain locally overlain by thin Late Eocene to Oligocene fluvial and lacustrine sediments (Migoń and Lidmar-Bergström 2001). At the same time, the Oligocene-Miocene and Pliocene basaltic volcanism penetrated the Sudetes and adjacent areas (Birkenmajer et al. 2004; Badura et al. 2005; Ulrych et al. 2011). Mid-Miocene to recent uplift and deformation of the Bohemian Massif can be attributed to lithospheric buckling and transpressional reactivation of pre-existing crustal discontinuities in response to the Neogene build up of intraplate compressional stresses that reflect increasing collisional coupling between the East Alpine-Carpathian orogenic wedge and its northern foreland (Ziegler et al. 2002; Ziegler and Dèzes 2007).

Studies on regional metamorphism within the Variscan belt showed that geothermal gradient reached $40-60{ }^{\circ} \mathrm{C} / \mathrm{km}$ near subvolcanic intrusions, where coal was locally formed (Teichmüller and Teichmüller 1986). However, the intense heat production of Variscan intrusions could raise this value locally to $90{ }^{\circ} \mathrm{C} / \mathrm{km}$ in the ISB (Kułakowski 1979). The lowest values of vitrinite reflectance are recorded around the basin margins $\left(0.6 \% \mathrm{R}_{\mathrm{r}}\right)$, while the highest ones appear in the centre (exceeding $4 \% R_{\max }$ ). Vitrinite reflectance gradients are high, reaching locally $0.6 \%$ per $100 \mathrm{~m}$ in the centre of the basin (Mastalerz and Jones 1988; Nowak 1993, 1996). The most intense coalification presumably took place during the 


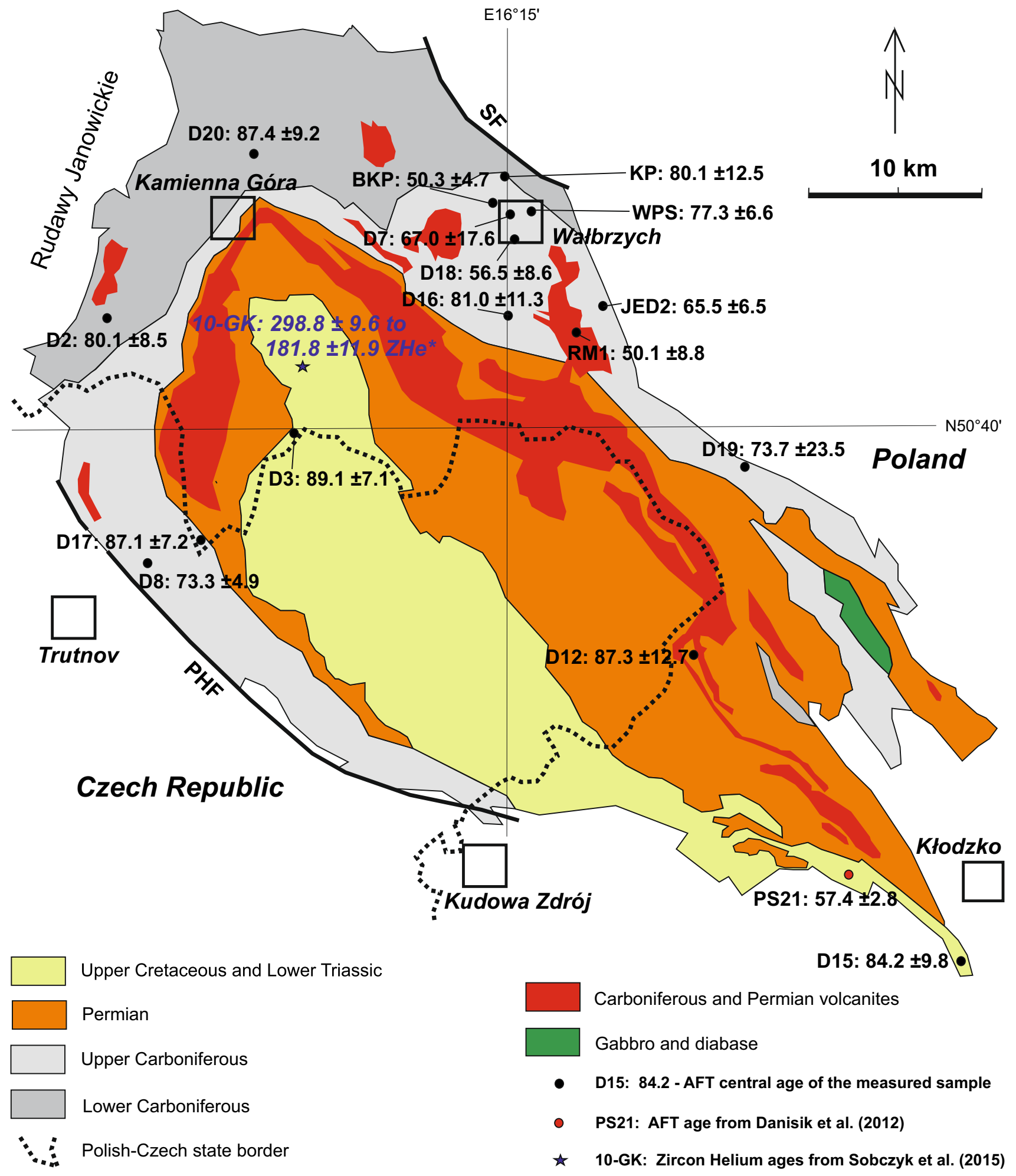

Fig. 2 Geological sketch map of the Intra-Sudetic Basin with AFT and zircon-helium (Sobczyk et al. 2015) data (geology is based on various sources including Grocholski and Augustyniak (1971),

Sawicki (1995), Bossowski and Ihnatowicz (2006). PHF PoříčíHronov Fault, SF Struga Fault 
Fig. 3 Lithostratigraphy of Intra-Sudetic Basin (Grocholski and Augustyniak 1971; Sawicki 1995; Bossowski and Ihnatowicz 2006)

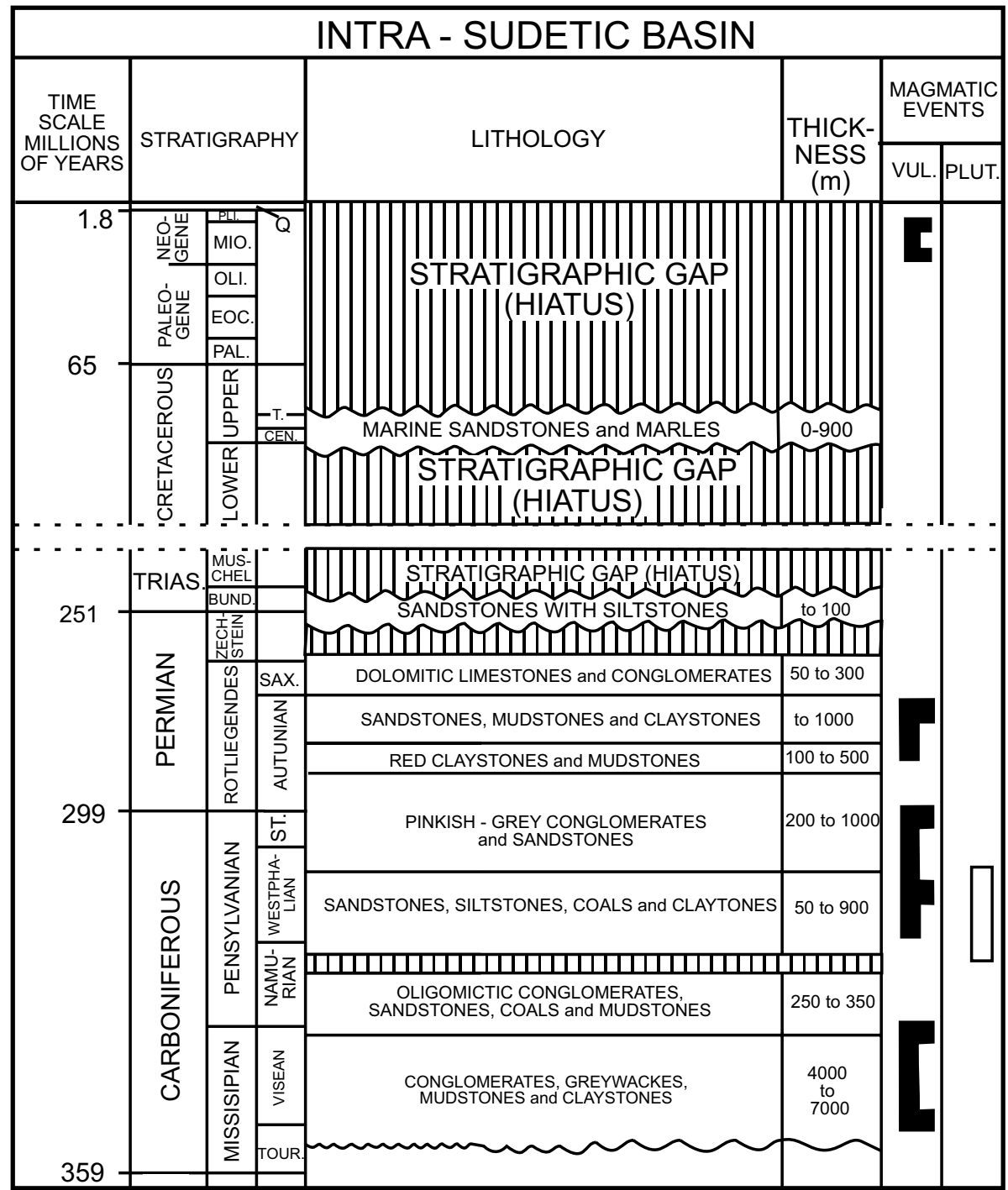

Westphalian A-B. The coalification temperature was estimated to be at least $\sim 160-170{ }^{\circ} \mathrm{C}$ with a geothermal gradient of $80-100{ }^{\circ} \mathrm{C} / \mathrm{km}$ (Mastalerz and Jones 1988). Maximum temperature could be even higher in the areas of high $R_{\max }$ values. Temperature estimated from maturity modelling using the Sweeney and Burnham (1990) approach gave values above $200-250{ }^{\circ} \mathrm{C}$ for bottom parts of the Carboniferous succession (Botor 2008).

\section{Samples and methods}

Apatite crystals of 16 samples, 15 sandstones and 1 volcanic rock were separated using conventional crushing, sieving, and magnetic and heavy liquids separation techniques.

Apatite grains were mounted in epoxy resin on glass slides and polished to expose grain surfaces. Spontaneous tracks were revealed by $5 \mathrm{~N} \mathrm{HNO}_{3}$ at $21{ }^{\circ} \mathrm{C}$ for $20 \mathrm{~s}$.
Neutron fluence (flux) was monitored using CN5 uranium dosimeter glass. Thin flakes of low-U muscovite were used as external detectors. Samples together with age standards (Fish Canyon, Durango, and Mount Dromedary apatite) and CN5 standard glass dosimeters were irradiated with a thermal neutron nominal flux of $9 \times 10^{15} \mathrm{n} / \mathrm{cm}^{2}$ at the Oregon State University TRIGA reactor (USA). After irradiation, muscovite was etched in $40 \% \mathrm{HF}$ for $45 \mathrm{~min}$ at $20{ }^{\circ} \mathrm{C}$ to reveal the induced tracks. For AFT analysis, we used the external detector and $\zeta$ age calibration methods to determine the fission track ages (Hurford and Green 1983; Hurford 1990). Track counting and length measurement of the horizontal confined fission tracks and the etch pit diameter (Dpar) values were carried out by means of optical microscopy at $1250 \times$ magnification using a Nikon Eclipse E-600, equipped with a motorised stage, digitising tablet and drawing tube controlled by the FTStage 4.04 programs (Dumitru 1993). All AFT ages are reported as central ages with $1 \sigma$ 
uncertainty (Galbraith and Laslett 1993). The degree to which individual AFT grain ages in a sample belong to a single population was assessed by $\mathrm{P}(\chi 2)$ statistic (Galbraith 1981). Values of $\mathrm{P}\left(\chi^{2}\right)$ below $5 \%$ indicate a statistically significant spread in single grain ages and the presence of more than one population (e.g. Galbraith 1981, 1990; Galbraith and Laslett 1993). A total of 437 confined track lengths (Gleadow et al. 1986) were measured in the studied samples. The measured confined track lengths were corrected for their crystallographic orientation by applying the computer code HeFTy to the data set (Donelick et al. 1999; Ketcham et al. 2007a). Measured data analyses and age calculations were accomplished using Trackkey 4.2 software (Dunkl 2002).

Thermal modelling of the analysed samples was performed using HeFTy software (Ketcham 2005). Based on our apatite fission track ages, confined track lengths and etch pits measurements, HeFTy defines a 'goodness of fit' (GOF) value in which a 'good' result corresponds to a value of 0.5 , an 'acceptable' result corresponds to a value of 0.05 and a GOF of 1 is the optimum time-temperature paths that pass baseline statistical criteria (Ketcham 2005). Thermal histories were modelled using the multi-kinetic model (Ketcham et al. 2007b) and Dpar values were used as kinetic parameters. The model c-axis projected length and c-axis projection were used (Ketcham et al. 2007b). Modelling results display cooling rates for the time interval corresponding to residence of sample within the temperature range of the apatite partial annealing zone (APAZ). Time-temperature $(\mathrm{t}-\mathrm{T})$ paths outside this range can only approach higher and lower temperature limits not matching the actual cooling rates. A time scale used was given by Gradstein et al. (2012). For a comprehensive overview of fission track methods and their modelling techniques, the reader is referred to Donelick et al. (2005), Ketcham (2005), Ketcham et al. (2007b) and Braun et al. (2006).

\section{Results}

\section{AFT central ages determinations}

The samples location is given in Fig. 2 and their stratigraphic position in Table 1. The results of AFT analyses for 16 samples are presented as central ages with errors of \pm 1 sigma (Table 1; Figs. 2, 4). The central AFT ages range from $50.1 \pm 8.8$ (Early Eocene) to $89.1 \pm 7.1 \mathrm{Ma}$ (Coniacian), although 13 out of 16 samples yielded more clustered central AFT ages between $65.5 \pm 6.5$ and $89.1 \pm 7.1 \mathrm{Ma}$ (Table 1, Fig. 2). Fourteen samples passed the Chi-squared probability test indicating that all grains in given sample belong to one homogeneous age population. Exceptions are only samples KP and WPS, which contain grains of several age assemblages. Since all the samples have central AFT ages significantly younger than their stratigraphic age, they must have experienced post-depositional temperatures more than $\sim 120{ }^{\circ} \mathrm{C}$ (for at least $10 \mathrm{Ma}$ ), leading to resetting of the AFT system.

\section{Track length measurements}

A total of 437 lengths of horizontal confined spontaneous fission tracks were measured ( 8 to 100 per sample except for sample D7, Table 2). The mean track length values range from $12.5 \pm 0.4$ to $14.4 \pm 0.2 \mu \mathrm{m}$, but most of them are lower than $13.8 \mu \mathrm{m}$ (Table 2). Most samples show a minor negative skewness between -0.1 and -0.7 (Table 2). The standard deviation (SD) values of track length range from 0.8 to $2.1 \mu \mathrm{m}$ (Table 2). The measured confined track lengths were corrected for their orientation to the crystallographic c-axis (Table 2). The corrected mean c-axis projected lengths are between 13.6 and $14.9 \mu \mathrm{m}$. The standard deviation values of the c-axis projected track length range from $0.7 \mu \mathrm{m}$ to $1.5 \mu \mathrm{m}$. The samples show skewness between -0.7 and 0.7 (Table 2).

The average etch pit diameter of tracks (Dpar) was measured for all samples (Table 2) as it is indicative of annealing kinetics of apatites (Barbarand et al. 2003; Donelick et al. 2005; Ketcham et al. 2007a, b). In each sample from 10 to 84 Dpar measurements were done. The mean Dpar value of the ISB samples are in the range of $2.1 \pm 0.6$ to $2.7 \pm 0.4 \mu \mathrm{m}$, except for the sample KP with Dpar of $1.8 \pm 0.4 \mu \mathrm{m}$ (Table 2 ), which generally corresponds to apatites being characterised by higher resistance annealing (Barbarand et al. 2003; Donelick et al. 2005). Except four samples, which show a negative skewness in the range of -0.9 to -0.1 , all other samples exhibit a positive skewness between 0 and 1.5. The larger skewness values indicate a larger variation in etch pit size (Table 2).

\section{Thermal modelling}

Inverse thermal modelling for samples D3 (Lower Triassic), D8, and BKP (Carboniferous) was carried out (Figs. 5, 6, 7) by means of HeFTy software (Ketcham 2005; Ketcham et al. 2007b, 2009). The modelling was implemented to test the thermochronological data set against geological constraints and investigate post-sedimentation time-temperature $(\mathrm{t}-\mathrm{T})$ paths. The low track length counts (8-36 CTL, Table 2) in the remaining 13 samples preclude their effective modelling. The calculations were performed until the software produced 100 good paths. The ensuing thermal history scenarios inferred from geological constraints available (see below) are potentially plausible for the study area and they were tested by different HeFTy models (Figs. 5, 6, 7). 


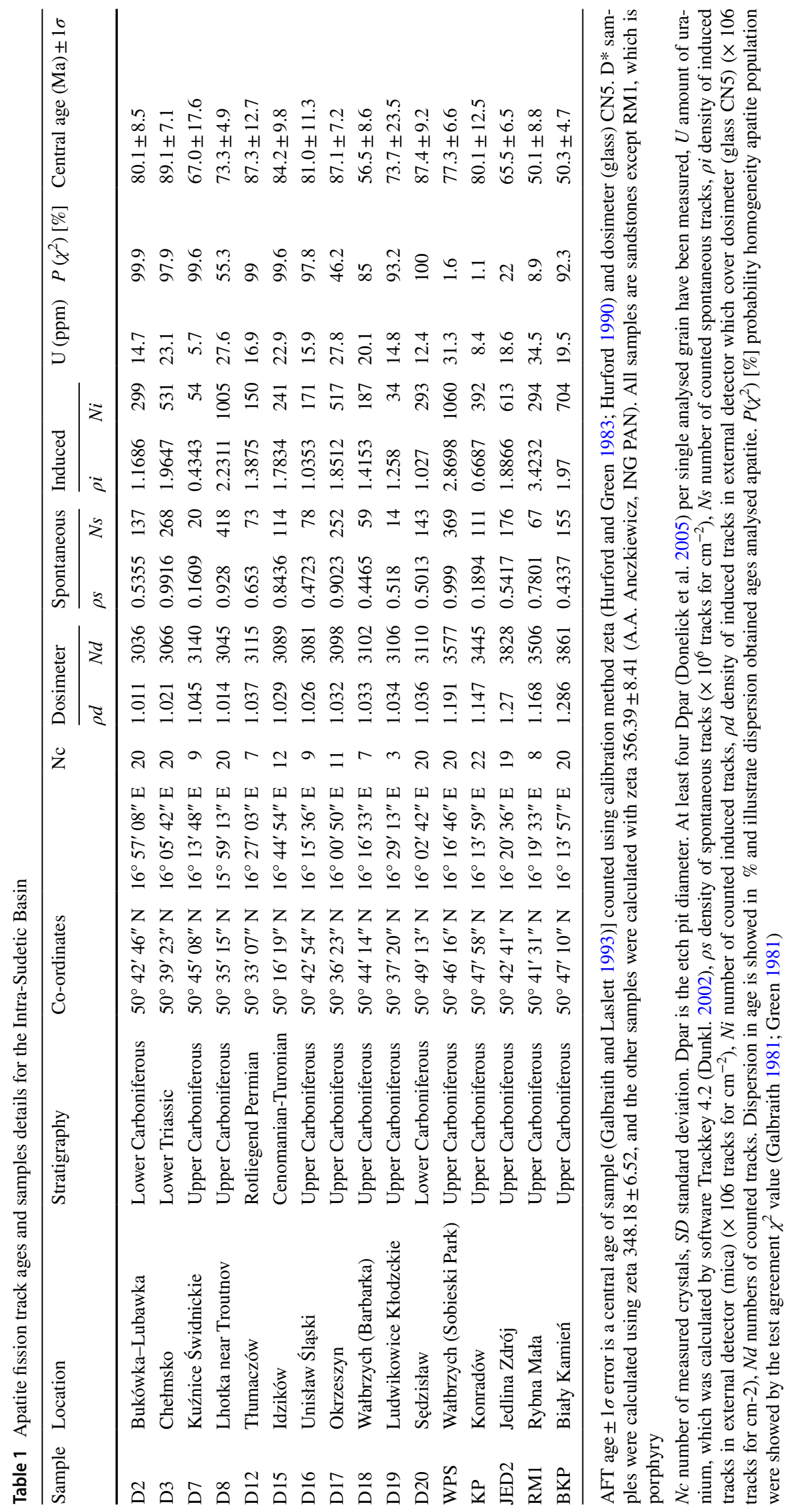



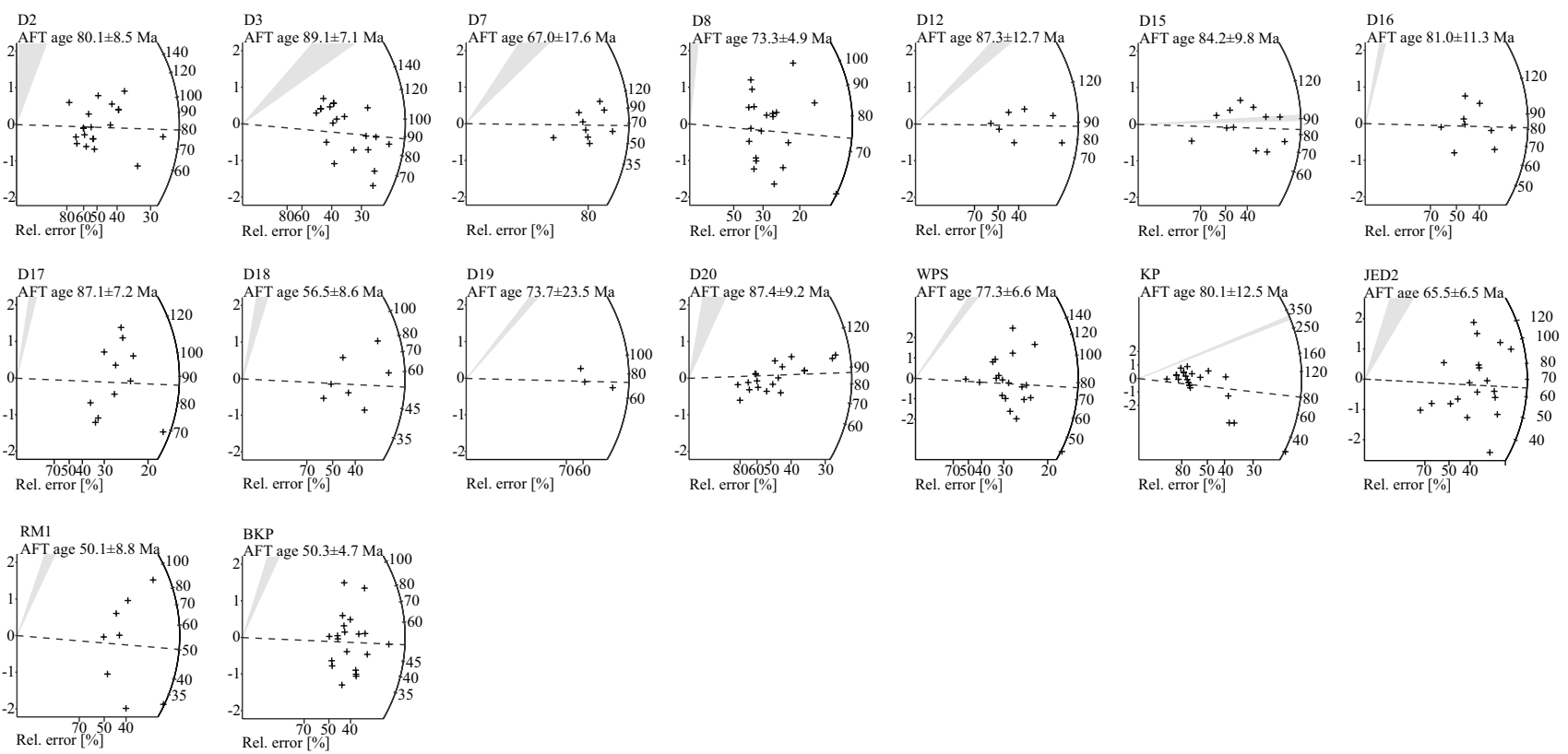

Fig. 4 Radial plots (Galbraith 1990) of the apatite samples from the Intra-Sudetic Basin, showing single grain AFT ages for each sample in Ma

\section{Modelling description and interpretation}

In sample D3 of the Lower Triassic age, the beginning of the $\mathrm{t}-\mathrm{T}$ paths is defined by the estimated ground temperature $\left(\sim 25 \pm 5^{\circ} \mathrm{C}\right)$ during the time of sample deposition $(\sim 248-249 \mathrm{Ma})$, while the end is set by the average presentday ground temperatures $\left(8^{\circ} \mathrm{C}\right)$. We initially allowed a temperature increase up to $180^{\circ} \mathrm{C}$ in the entire post-depositional period (from the Mid-Triassic to Cenozoic) (Fig. 5a). Such a model shows the increase of temperature in the Triassic and final cooling in the Late Cretaceous/Paleogene. GOF values are high (0.95 and 0.88), suggesting that a time-temperature (t-T) path is plausible. The most significant temperature increase occurs in the Late Triassic-Early Jurassic in agreement with $\mathrm{ZHe}$ ages from the Variscan external zone (Kowalska et al. 2015, Botor et al. 2017b). Another model with maximum temperatures during the Mid-Late Cretaceous (Fig. 5b) was created to test a significant Late Cretaceous burial in the Sudetes ( 4-6 km of Cenomanian and Turonian sediments) as suggested east and west of our study area by Danišík et al. (2012) and Sobczyk et al. (2015), respectively. This model postulates a near surface position for sample D3 prior to the Mid-Late Cretaceous transgression. A time window was set to 95-0 Ma and a temperature range to $25-180{ }^{\circ} \mathrm{C}$ based on the sedimentary record from the Cretaceous basins around the Sudetes (Skoček and Valečka 1983) but allowing for a wider $t-T$ range. Since very good GOF values (1.0 and 0.98 ) are obtained both thermal history models tested for sample D3 ( $a$ and b, in Fig. 5) appear equally possible. Additionally, we tried a model with the beginning of constraint box at $120 \mathrm{Ma}$ and it also provided similar results (Fig. 5c).

For the Carboniferous samples (BKP and D8), the beginning of the $\mathrm{t}-\mathrm{T}$ paths was defined by the estimated annual mean temperature $\left(\sim 25 \pm 5^{\circ} \mathrm{C}\right)$ during the time of deposition ( 325-315 Ma), while their end was limited by the average present-day temperature $\left(8^{\circ} \mathrm{C}\right)$. A temperature in the constrain boxes was set to vary within the range of 20 to $180{ }^{\circ} \mathrm{C}$ that is wider than sensitivity of the AFT method to avoid forcing any solutions. Modelling was initially performed without any other limitations, but the resultant models were unsuccessful. There were no resulting paths that passed the baseline statistical criteria. Therefore, for a next set of models, we assumed post-Variscan cooling to the near-surface temperatures in the Early Triassic that was followed by thermal stagnation without any significant reheating until recent times (Figs. 6a, 7a). In another variant of this scenario, we assumed heating in the Variscan time, but without forcing a low-temperature $\mathrm{t}-\mathrm{T}$ constraint during the post-Permian history (Figs. 6b, 7b). Despite different constraints applied the resultant model was similar to the previous one (compare Figs. 6a, 7a vs Figs. 6b, 7b). Consequently, a thermal peak in samples BKP and D8 was achieved in the Late Carboniferous ( $\sim$ Late Westphalian-Stephanian; Kułakowski 1979; Mastalerz and Jones 1988) or latest Carboniferous to Early Permian (Botor 2008). This Variscan thermal peak was followed by slow cooling in the Late Permian-Mesozoic, long residence in the APAZ and final acceleration of cooling in the Late Cretaceous-Paleogene (Figs. 6a, b, 7a, b). GOF values obtained are high (0.89 to 0.99$)$ show that 


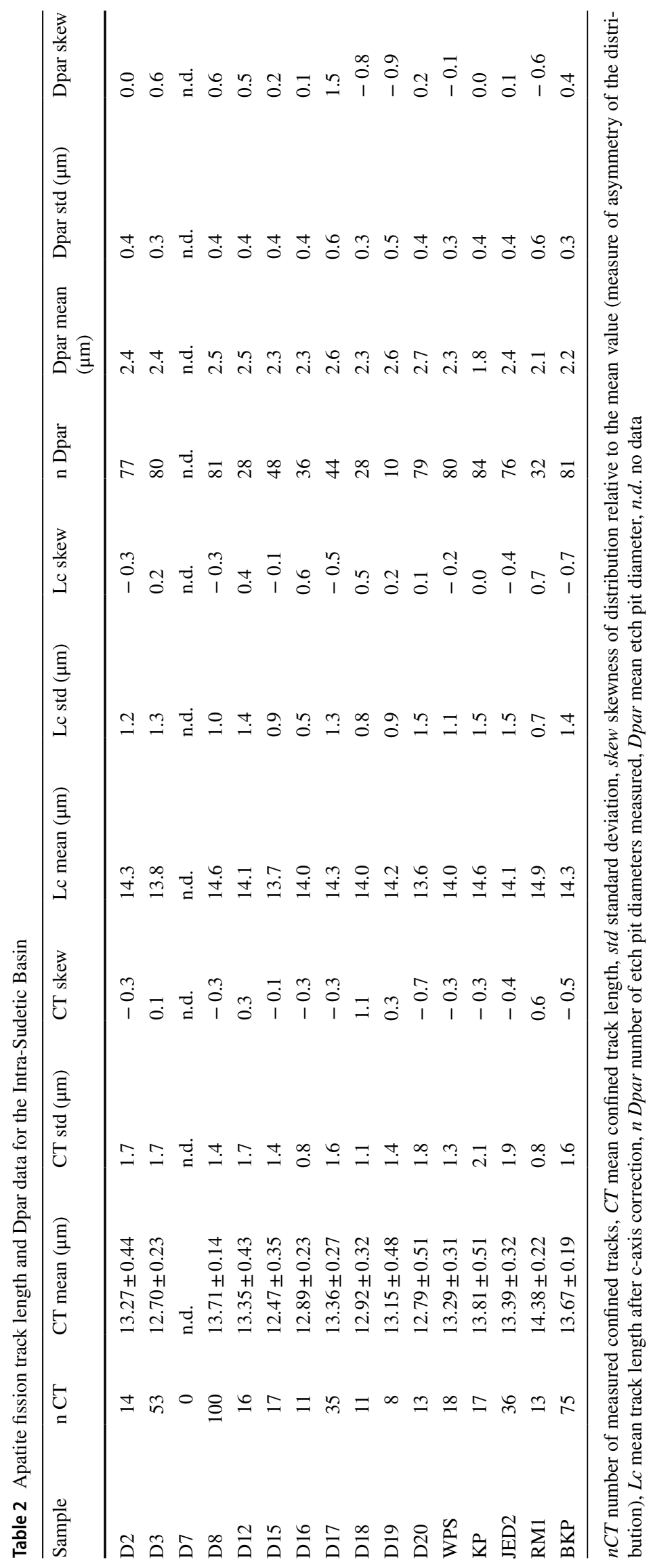



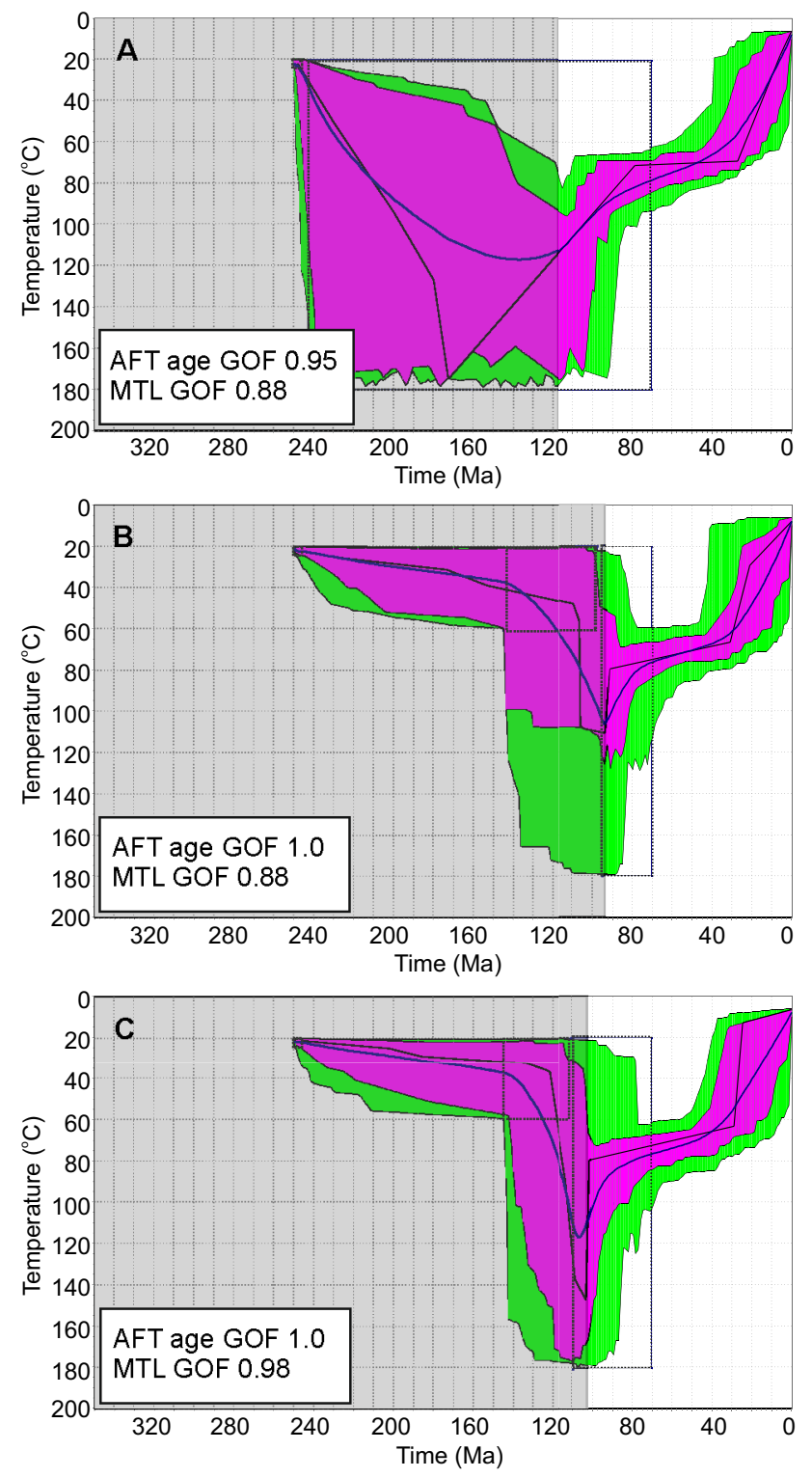

Fig. 5 Thermal modelling results of Lower Triassic sample D3 from the Intra-Sudetic Basin. Thermal modelling has been performed by HeFTy software (Ketcham 2005). The measured confined track lengths were corrected for their crystallographic orientation by applying the computer code HeFTy to the data set (Donelick et al. 1999; Ketcham et al. 2007a). GOF goodness of fit (statistical comparison of the measured input data and modelled output data). An acceptable fit (green range) corresponds to these thermal histories that give a goodness of fit (GOF) value greater than 0.05 for both the age and the length distribution (Ketcham 2005). A good fit (purple range) corresponds to thermal histories with a GOF value $>0.5$ (for modelling strategy details, see Ketcham et al. 1999, 2007a, b; Ketcham 2005). A starting point $\left(\sim 245 \mathrm{Ma} ; 25^{\circ} \mathrm{C}\right)$ and the present-day point $(0 \mathrm{Ma}$; $8{ }^{\circ} \mathrm{C}$ ) were applied in the modelling. The independent inserted boxes (black-dashed rectangles) for the heating/cooling periods have a maximum temperature range above value $120^{\circ} \mathrm{C}$ to allow for undisturbed $\mathrm{t}-\mathrm{T}$ modelling. Black line is the best fit curve for which GOF values are given, whereas dark navy blue line is an average curve with good fit (in purple range). Greyish parts of the models represent sections of $\mathrm{t}-\mathrm{T}$ paths that are not constrained by AFT data. Further explanations in the text
Variscan heating event, succeeded by post-Variscan cooling, is enough to explain our AFT data (Figs. 6a, b, 7a, b). Consequently, Cretaceous burial was not necessary for resetting the AFT system. The BKP and D8 samples resided in the AFT annealing zone until the Late Cretaceous, when acceleration of cooling occurred (Figs. 6a, b, 7a, b).

The next thermal history model for samples BKP and D8 (Fig. 6c, 7c) assumed post-Variscan cooling to the nearsurface temperatures in the Early Triassic and successive reheating in the Late Triassic-Early Jurassic. This is justified by possible increase of heat flow in the Mesozoic in association with an extensional regime dominating over the NE Bohemian Massif and Variscan foreland at that time (Kowalska et al. 2015; Botor et al. 2017a, b). These models also gave good GOF values (0.94-0.99).

The last set of thermal models for samples BKP and D8 (Figs. 6d and 7d) postulates significant Mid-Cretaceous burial in the Sudetes as suggested by Danišík et al. (2012) and Sobczyk et al. (2015). These authors assumed maximum basement temperatures during the Late Cretaceous based on ZHe data. Therefore, constraint boxes were set to 95-70 Ma $\left(20-180{ }^{\circ} \mathrm{C}\right)$ based on the sedimentary record in the Cretaceous basins (Skoček and Valečka 1983). In such a case, Cretaceous burial can be treated as post-Variscan reheating (Fig. 6d, 7d). In both these models, GOF values are similar (0.94-0.98). Another variant of the Mid-Cretaceous burial scenario is to assume that the samples were relatively close to the surface during the Early Cretaceous prior to the Late Cretaceous transgression (Figs. 6e, 7e). However, if we assume a constrain box from the Mid-Triassic to Early Cretaceous, the increase of temperature is earlier, not supporting the Mid-Cretaceous burial model (Figs. $6 \mathrm{f}$ and $7 \mathrm{f}$ ). Therefore, despite high GOF values (0.94-1.0), the model of Mid-Cretaceous burial is only consistent with the AFT data, if an Early Cretaceous constrain box is assumed showing surface conditions at that time (Figs. 6e and 7e). Generally, longer residence in a higher temperature range in the Mesozoic gives slightly better GOF values for the BKP and D8 samples. Neither tested models nor measured AFT data show reheating in the Cenozoic in association with Neogene volcanism present in the Sudetes (e.g. Birkenmajer et al. 2004; Badura et al. 2005).

\section{Discussion}

The Coniacian to Early Eocene AFT central ages (89-50 Ma) of the Carboniferous, Lower Triassic and Cenomanian-Turonian samples indicate resetting during the post-depositional history. The AFT ages do not show correlation with the elevation of sampling sites, because of flat topography with denivelations less than $300 \mathrm{~m}$. There is also no clear trend in a regional distribution of the AFT 

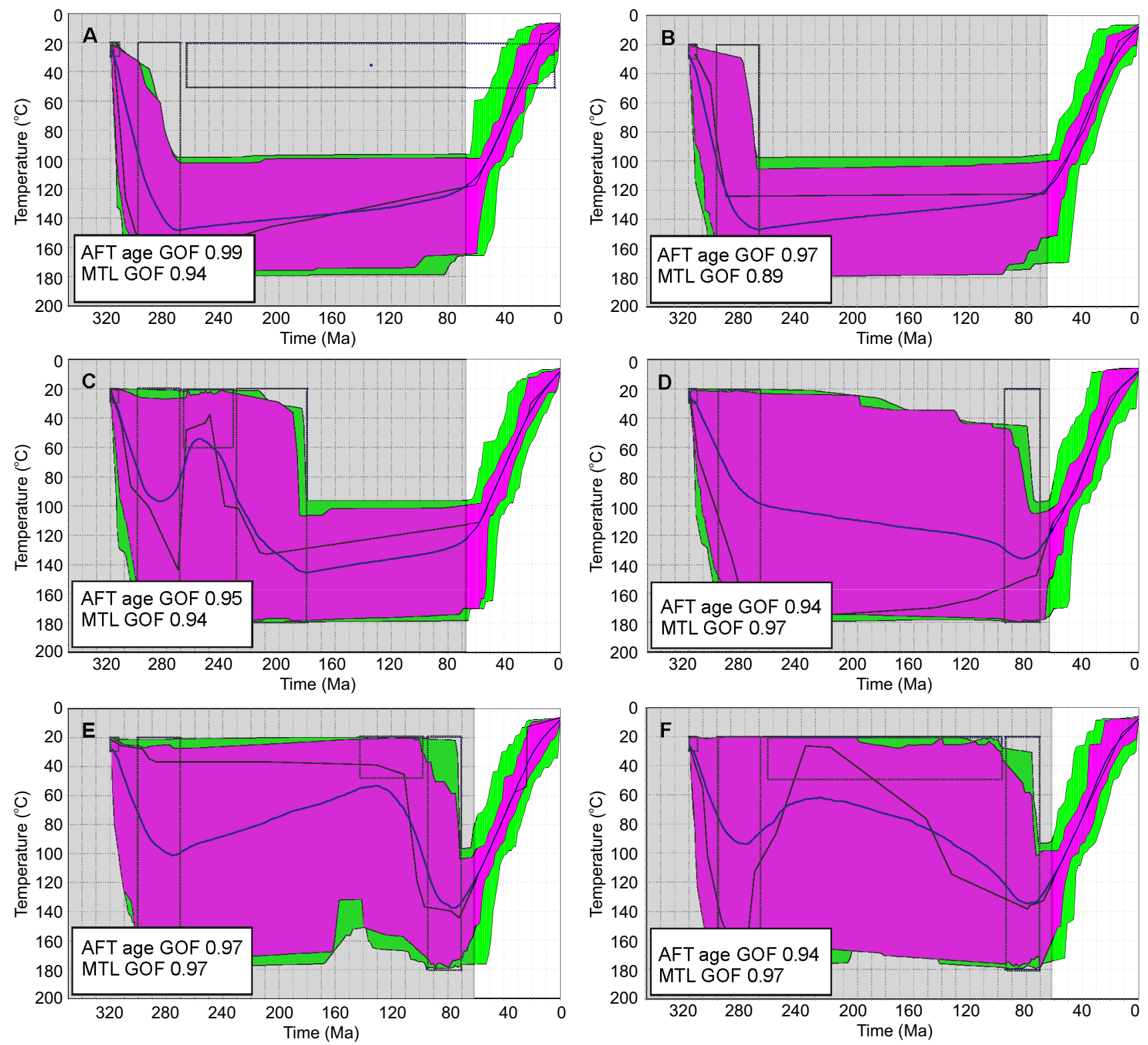

Fig. 6 Thermal modelling results of Carboniferous sample BKP from the Intra-Sudetic Basin that has been performed by HeFTy software (Ketcham 2005). A starting point ( $\left.324 \mathrm{Ma} ; 25^{\circ} \mathrm{C}\right)$ and the present-day point $\left(0 \mathrm{Ma} ; 8{ }^{\circ} \mathrm{C}\right)$ were applied in the modelling. See explanations in Fig. 5

ages. The unimodal track length distributions, relatively short mean track length and rather low standard deviation $(0.8$ to $1.7 \mu \mathrm{m}$, Table 2$)$, indicate a relatively simple thermal history that could have been related to a heating event in temperatures exceeding $120^{\circ} \mathrm{C}$ (for at least $10 \mathrm{Ma}$ ), followed by prolonged residence in the APAZ and final cooling. Slightly wider track length distributions in the samples from the northern part of the ISB (Table 2) may indicate a more complex thermal evolution due to some reheating or longer residence in the APAZ. Consistently with this scenario, samples of BKP and D8 show that latest Carboniferous-Early Permian heating that was followed by slow cooling with long residence in the APAZ is enough to explain the AFT data obtained (Figs. 6a, b, $7 \mathrm{a}, \mathrm{b})$. However, Lower Triassic sample D3 showed that some Mesozoic reheating is necessary for resetting the AFT ages (Fig. 5). Since the Carboniferous samples must have gone through a similar thermal history as the overlying Lower Triassic rocks, they should have also experienced Mesozoic reheating. Indeed, thermal models for the D8 and BKP samples involving Mesozoic reheating produce equally good calibration compared to those postulating only Variscan heating. Therefore, the models implying Mesozoic reheating are accepted here as an optimal 

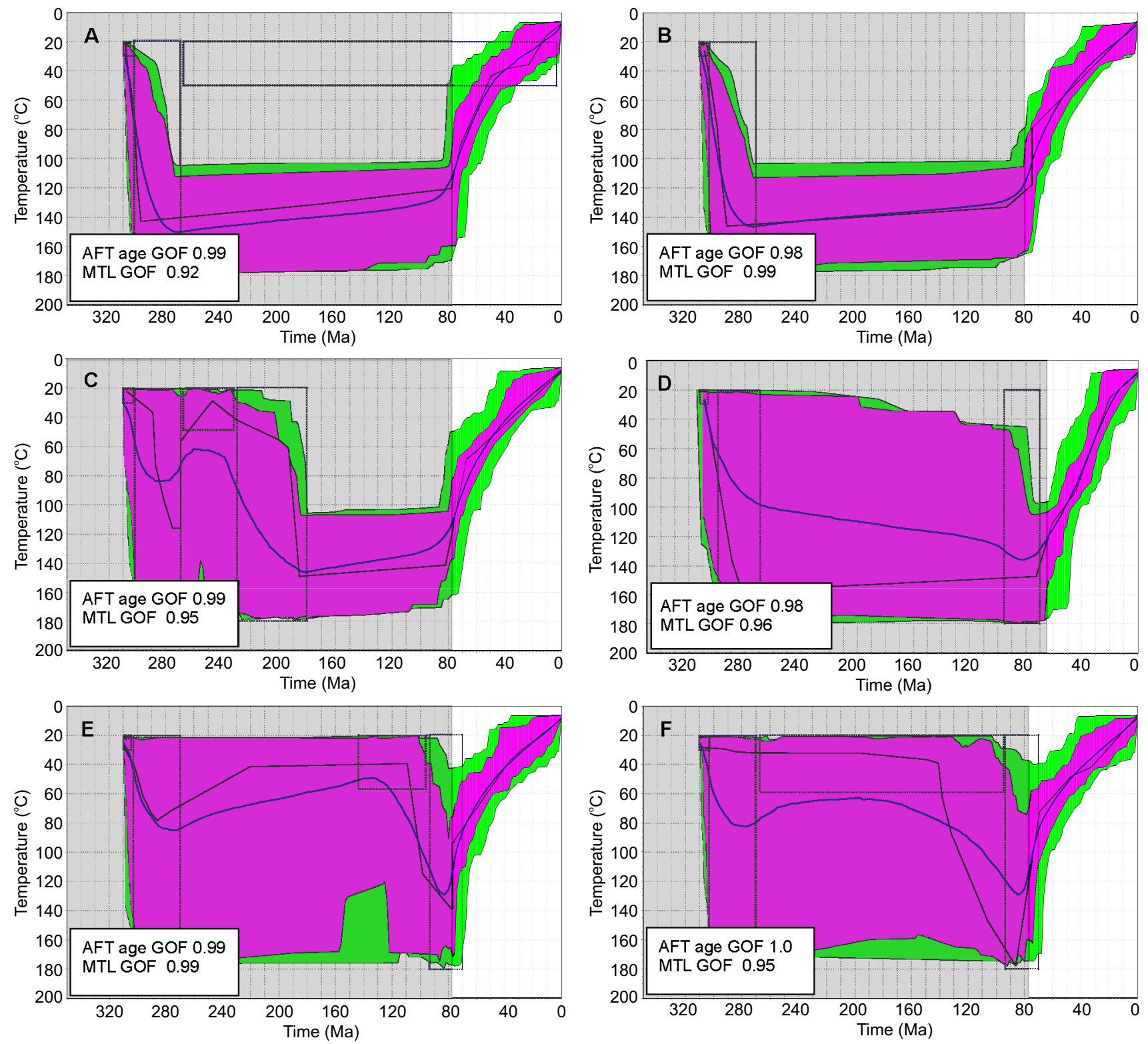

Fig. 7 Thermal modelling results of Carboniferous sample D8 from the Intra-Sudetic Basin that has been performed by HeFTy software (Ketcham 2005). A starting point ( $\left.315 \mathrm{Ma} ; 25^{\circ} \mathrm{C}\right)$ and the present-day point $\left(0 \mathrm{Ma} ; 8{ }^{\circ} \mathrm{C}\right)$ were applied in the modelling. See explanations in Fig. 5

solution regardless the cause and timing of Mesozoic event. Moreover, Cenomanian-Turonian sample D15 (Table 1), not used for modelling, because of too low track length counts, as well as sample PS-21 from Danišík et al. (2012), having totally reset AFT system, point to a Late Cretaceous thermal event. Thermal maturity of organic matter occurring in the Carboniferous sediments of the ISB is generally high $(\sim 1-4 \%$ vitrinite reflectance), which document maximum temperatures much above $\sim 120{ }^{\circ} \mathrm{C}$. Since the AFT system is sensitive in the temperature range of $60-120^{\circ} \mathrm{C}$, Carboniferous thermal history above $120^{\circ} \mathrm{C}$ is not recorded by our approach.
Although our Cretaceous samples do not have enough confined track length data for robust $\mathrm{t}-\mathrm{T}$ modelling, they document maximum temperature above $\sim 120{ }^{\circ} \mathrm{C}$. Taking also into account the lack of reset of $\mathrm{ZHe}$ age in Cretaceous sample 10-GK from Sobczyk et al. (2015), the maximum temperature experienced by the Cenomanian-Turonian samples can be inferred in the range of $\sim 120-130{ }^{\circ} \mathrm{C}$. These data show that the rocks presently exposed in the ISB were at depths of $\sim 4 \mathrm{~km}$ during the Mid-Late Cretaceous, applying the present-day geothermal gradient of $24^{\circ} \mathrm{C} / \mathrm{km}$ (Čermak 1968; Bruszewska 2000) and an average Cretaceous surface temperature of $20^{\circ} \mathrm{C}$ (e.g. Thomson and Zeh 2000). In the 
absence of data confirming a high heat flow regime in the Late Cretaceous, sedimentary burial hypothesis seems to be the most plausible. There was no reheating in the Cenozoic despite several occurrences of basaltic volcanic rocks in the Sudetes (Birkenmajer et al. 2004; Badura et al. 2005).

Deposition of sedimentary overburden responsible for Late Cretaceous reheating was related to Cenomanian transgression of a shallow sea over the northern part of the Bohemian Massif (e.g. Skoček and Valečka 1983; Uličný 2001). According to classical paleogeographic models, a thickness of Upper Cretaceous sediments was only $1000 \mathrm{~m}$ and large parts of the Sudetes, including the study area, were emerged as an archipelago of islands within a shallow sea (Scupin 1936; Milewicz 1997; Skoček and Valečka 1983). However, Danišík et al. (2012) and Sobczyk et al. (2015) proposed that the entire Sudetes were buried beneath a significant cover of Upper Cretaceous sediments in the range of 3.5-6 km. Our AFT data support this view as they imply $\sim \mathrm{km}$ of burial to justify a Late Cretaceous reheating event.

Both Palaeozoic and Mesozoic samples show relatively uniform Late Cretaceous AFT ages that reveal a distinct cooling event affecting all samples from the study area. This event corresponds to Late Cretaceous inversion of the European Basin System (Scheck et al. 2002) that was related to Europe-Iberia-Africa plate convergence (Kley and Voigt 2008). Inversion resulted in uplift of sedimentary basins, local folding, thrusting and exhumation of some basement blocks in the Sudetes (Malkovský 1987; Scheck et al. 2002; Aramowicz et al. 2006; Ventura et al. 2009; Danišík et al. 2010, 2012). The distinct cluster of Late Cretaceous-Paleogene AFT ages found in most of our samples and the thermal modelling results show that this was the time, when all the samples finally cooled through the APAZ $\left(\sim 60-120^{\circ} \mathrm{C}\right)$ to near-surface temperature conditions. The cooling might be considered the result of exhumation related to erosion of the Cretaceous sedimentary cover as it was suggested for the adjacent areas by Danišík et al. $(2010,2012)$ and Sobczyk et al. (2015).

Our results are comparable to those obtained in the Lower Saxony Basin (northern Germany), where AFT ages indicate a major cooling event in the Late Cretaceous ( 89-72 Ma) reflecting the time of basin inversion (Senglaub et al. 2005). In the nearby Lusatian Block (eastern Germany), AFT analysis of basement rocks yields ages varying between approximately 70 and $95 \mathrm{Ma}$ (Ventura et al. 2009). Thermal history modelling of the AFT data points to a minimum denudation of $3 \mathrm{~km}$ in the Late Cretaceous (Ventura et al. 2009). The AFT ages by Sobczyk et al. (2015) range from 105.9 \pm 6.1 to $51.1 \pm 4.3 \mathrm{Ma}$ for the Rudawy Janowickie (Fig. 2) at the NW margin of the ISB, supporting at least 3.3-3.5 km of exhumation since the Cenomanian. This fits well to our estimates of $\sim 4 \mathrm{~km}$ of total erosion since the Late Cretaceous reheating event consistent with a denudation rate of $\sim 70 \mathrm{~m} \mathrm{myr}^{-1}$ for the Late Cretaceous and Palaeogene.

\section{Conclusions}

AFT central ages of Carboniferous to Turonian samples from the ISB range from $89.1 \pm 7.1$ to $50.1 \pm 8.8 \mathrm{Ma}$ (Coniacian to Early Eocene), but most of them are Late Cretaceous. These results indicate that studied rocks were heated to temperatures above $\sim 120{ }^{\circ} \mathrm{C}$, which is sufficient to totally anneal apatite fission tracks.

The AFT data used for thermal modelling are largely insensitive to the thermal history before $\sim 100 \mathrm{Ma}$ (Mid Cretaceous). Whatever constraints are used for a time slice before $100 \mathrm{Ma}$, it does not change the result after $100 \mathrm{Ma}$. Therefore, the models obtained are robust enough to justify a Late Cretaceous reheating event and constrain the cooling history of the basin inversion. Furthermore, they demonstrate that $\sim 4 \mathrm{~km}$ thick cover of Upper Cretaceous sediments is required to obtain a good match between our AFT data and modelled time-temperature paths. The Late Cretaceous-Palaeogene cooling phase was related to tectonic inversion that caused the present-day exposure of the ISB.

High level of thermal maturity of the organic matter within Carboniferous rocks is related to a major coalification phase in the latest Carboniferous to Early Permian. The second phase of temperature increase due to Mesozoic sedimentary burial did not exceed the temperatures experienced by the Carboniferous samples in the Late Palaeozoic. Therefore, the Mesozoic temperature increase does not appear to have any noticeable influence on the maturation of the Carboniferous organic matter in the ISB.

Acknowledgements This work was partially financed by AGH statutory grants no. 11.11.140.562 and 16.16.140.315. Anonymous reviewers are thanked for their insightful comments.

Open Access This article is distributed under the terms of the Creative Commons Attribution 4.0 International License (http://creativeco mmons.org/licenses/by/4.0/), which permits unrestricted use, distribution, and reproduction in any medium, provided you give appropriate credit to the original author(s) and the source, provide a link to the Creative Commons license, and indicate if changes were made.

\section{References}

Aramowicz A, Anczkiewicz AA, Mazur S (2006) Fission track dating of apatites from the Góry Sowie Massif, Polish Sudetes, NE Bohemian Massif: implications of post-Variscan denudation and uplift. Neues Jahrbuch für Mineralogie Abhandlunge 182(3):221-229. https://doi.org/10.1127/0077-7757/2006/0046 
Awdankiewicz M (1999a) Volcanism in a late Variscan intramontane trough: Carboniferous and Permian volcanic centres of the IntraSudetic Basin, SW Poland. Geologia Sudetica 32:13-47

Awdankiewicz M (1999b) Volcanism in a late Variscan intramontane trough: the petrology and geochemistry of the Carboniferous and Permian volcanic rocks of the Intra-Sudetic Basin, SW Poland. Geologia Sudetica 32:83-111

Awdankiewicz M (2004) Sedimentation, volcanism and subvolcanic intrusions in a late Palaeozoic intramontane trough (the IntraSudetic Basin, SW Poland). Geol Soc 234:5-11. https://doi. org/10.1144/GSL.SP.2004.234.01.02

Badura J, Pecskay Z, Koszowska E, Wolska A, Zuchiewicz W, Przybylski B (2005) New age and petrological constraints on Lower Silesian basaltoids, SW Poland. Acta Geodynamica et Geomaterialia 2(3):7-15

Barbarand J, Carter A, Wood I, Hurford T (2003) Compositional and structural control of fission track annealing in apatite. Chem Geol 198:107-137. https://doi.org/10.1016/S0009-2541(02)00424-2

Birkenmajer K, Pécskay Z, Grabowski J, Lorenc MW, Zagożdżon PP (2004) Radiometric dating of the Tertiary volcanics in Lower Silesia, Poland. IV. Further K-Ar and palaeomagnetic data from Late Oligocene to Early Miocene basaltic rocks of the Fore-Sudetic Block. Annales Societatis Geologorum Poloniae 74(1):1-19

Bossowski A, Ihnatowicz A (1994) Palaeogeography of the Upper Carboniferous coal-bearing deposits in NE part of the Intra-Sudetic Depression. Geol Q 38:231-248

Bossowski A, Ihnatowicz A (2006) Geological atlas of the Lower Silesian Coal Basin. Państwowy Instytut Geologiczny, Warsaw

Botor D (2008) Thermal History of the coal-bearing Carboniferous rocks in the Wałbrzych district (Lower Silesia Coal Basin, Poland) constrained by a numerical maturity modelling. Zeszyty Naukowe Politechniki Śląskiej w Gliwicach 286:15-24

Botor D, Toboła T, Jelonek I (2017a) Thermal history of the Lower Carboniferous Culm Basin in the Nízký Jeseník Mts. (NE Bohemian Massif, Czech Republic and Poland). Annales Societatis Geologorum Poloniae 87(1):13-40

Botor D, Dunkl I, Anczkiewicz A, Mazur S (2017b) Post-Variscan thermal history of the Moravo-Silesian lower Carboniferous Culm Basin (NE Czech Republic-SW Poland). Tectonophysics 712713:643-662. https://doi.org/10.1016/j.tecto.2017.06.035

Braun J, Van der Beek P, Batt G (2006) Quantitative thermochronology. Cambridge University Press. 272 pp, https://doi.org/10.1017/ CBO9780511616433

Bruszewska B (2000) The geothermal conditions in Lower Silesia (SW Poland). Przegląd Geologiczny 48:639-643 (in Polish with English summary)

Čermak V (1968) Heat flow in the Zacler-Svatonovice Basin. Acta Geophysica Polonica 16:3-9

Danišík M, Migoń P, Kuhlemann J, Evans NJ, Dunkl I, Frisch W (2010) Thermochronological constraints on the long-term erosional history of the Karkonosze Mts., Central Europe. Geomorphology 117:78-89. https://doi.org/10.1016/j.geomorph.2009.11.010

Danišík M, Štěpančiková P, Evans NJ (2012) Constraining long-term denudation and faulting history in intraplate regions by multisystem thermochronology - an example of the Sudetic Marginal Fault (Bohemian Massif, Central Europe). Tectonics 31(2):1-19. https://doi.org/10.1029/2011TC003012

Donelick RA, Ketcham RA, Carlson WD (1999) Variability of apatite fission track annealing kinetics: II. crystallographic orientation effects. Am Miner 84:1224-1234. https://doi.org/10.2138/ am-1999-0902

Donelick RA, O'Sullivan PB, Ketcham RA (2005) Apatite fission track analysis. Rev Mineral Geochem 58:49-94. https://doi. org/10.2138/rmg.2005.58.3
Dumitru T (1993) A new computer-automated microscope stage system for fission track analysis. Nucl Tracks Radiat Meas 21:575-580. https://doi.org/10.1016/1359-0189(93)90198-I

Dunkl I (2002) Trackkey: a Windows program for calculation and graphical presentation of fission track data. Comput Geosci 28:312. https://doi.org/10.1016/S0098-3004(01)00024-3

Dziedzic K (1971) Sedimentation and palaeogeography of the Upper Carboniferous deposits in the Intra-Sudetic depression. Geologia Sudetica 5:7-75 (in Polish with English summary)

Dziedzic K, Teisseyre AK (1990) The Hercynian mollase and younger deposits in the Intra-Sudetic Basin, SW Poland. Neues Jb Geol Paläontol Abh 197:285-305

Feist-Burkhardt S, Götz AE, Szulc J, Borkhataria R, Geluk M, Haas J, Hornung J, Jordan P, Kempf O, Michalik J, Nawrocki J, Reinhardt L, Ricken W, Röhling HG, Rüffer T, Török Á, Zühlke R (2008) Triassic. In: McCann T (ed) The Geology of Central Europe. The Geological Society, London, pp 749-822

Franke W, Dallmeyer RD, Weber K (1995) Geodynamic evolution. In: Dallmeyer RD, Franke W, Matte P (eds) Pre-permian geology of Central and Eastern Europe. Springer-Verlag, Berlin, pp 579-593

Galbraith RF (1981) On statistical models for fission track counts. Math Geol 13(6):471-478

Galbraith RF (1990) International Journal of Radiation Applications and Instrumentation, Part D. Nucl Tracks Radiat Meas 17(3):207214. https://doi.org/10.1016/1359-0189(90)90036-W

Galbraith RF, Laslett GM (1993) Statistical models for mixed fission track ages. Nucl Tracks Radiat Meas 21:459-470. https://doi. org/10.1016/1359-0189(93)90185-C

Glasmacher UA, Mann U, Wagner GA (2002) Thermotectonic evolution of the Barrandian, Czech Republic, as revealed by apatite fission-track analysis. Tectonophysics 359:381-402. https://doi. org/10.1016/S0040-1951(02)00538-3

Gleadow AJW, Duddy IR, Green PF, Lovering JF (1986) Confined fission track lengths in apatite: a diagnostic tool for thermal history analysis. Contrib Mineral Petrol 94:405-415. https://doi. org/10.1007/BF00376334

Gradstein FM, Ogg JG, Hilgen FJ (2012) On the geologic time scale. Newsl Stratigr 45:171-188. https://doi. org/10.1127/0078-0421/2012/0020

Green PF (1981) 'Track-in track' length measurements in annealed apatites. Nucl Tracks 5:12-18

Grocholski A, Augustyniak K (1971) Geological Atlas of the Lower Silesian Coal Basin. Wydawnictwa Geologiczne, Warszawa

Hejl E, Coyle D, Lal N, Van den Haute P, Wagner GA (1997) Fission-track dating of the western border of the Bohemian massif: thermochronology and tectonic implications. Geol Rundsch 86:210-219. https://doi.org/10.1007/s005310050133

Hejl E, Sekyra G, Friedl G (2003) Fission-track dating of the southeastern Bohemian Massif (Waldviertel, Austria): thermochronology and long-term erosion. Int J Earth Sci 92:677-690. https:// doi.org/10.1007/s00531-003-0342-y

Hurford AJ (1990) Standardization of fission track dating calibration: recommendations by the Fission Track Working Group of the I.U.G.S. Subcommission on Geochronology. Chem Geol 80:171178. https://doi.org/10.1016/0168-9622(90)90025-8

Hurford AJ, Green PF (1983) The zeta age calibration of fission track dating. Chem Geol 41:285-312. https://doi.org/10.1016/S0009 -2541(83)80026-6

Jarmołowicz-Szulc K (1984) Geochronological study of the northern cover of the Karkonosze granite by fission track method. Arch Mineral 39:139-183

Jarmołowicz-Szulc K, Hałas S, Wojtowicz A (2009) Radiometric age analyses of rocks from the northern envelope of the Karkonosze Massif, the Sudetes, Poland: a comparative geochronological 
study. Geochronometria 34:33-39. https://doi.org/10.2478/v1000 3-009-0016-2

Ketcham RA (2005) Forward and inverse modeling of low-temperature thermochronometry data. Rev Mineral Geochem 58:275-314. https://doi.org/10.2138/rmg.2005.58.11

Ketcham RA, Donelick RA, Carlson WD (1999) Variability of apatite fission track annealing kinetics III: Extrapolation to geological time scales. Am Mineral 84:1235-1255

Ketcham RA, Carter A, Donelick RA, Barbarand J, Hurford AJ (2007a) Improved measurement of fission track annealing in apatite using c-axis projection. Am Miner 92:789-798. https://doi.org/10.2138/ am.2007.2280

Ketcham RA, Carter A, Donelick RA, Barbarand J, Hurford AJ (2007b) Improved modeling of fission track annealing in apatite. Am Miner 92:799-810. https://doi.org/10.2138/am.2007.2281

Ketcham RA, Donelick RA, Balestrieri ML, Zattin M (2009) Reproducibility of apatite fission-track length data and thermal history reconstruction. Earth Planet Sci Lett 284(3-4):504-515. https ://doi.org/10.1016/j.epsl.2009.05.015

Kley J, Voigt T (2008) Late Cretaceous intraplate thrusting in central Europe: effect of Africa-Iberia-Europe convergence, not Alpine collision. Geology 36:839-842. https://doi.org/10.1130/G2493 0A. 1

Kowalska S, Wolański K, Botor D, Dunkl I, Wójtowicz A, Jonkis U, Buniak A (2015) Complex thermal history reconstruction of Carboniferous rocks from the Fore-Sudetic Monocline-application in a tight gas exploration of illite K-Ar and Zircon helium dating. EuroClay Conference, Abstract Book. Edinburgh, UK, 5-10.07.2015, p. 428

Kułakowski T (1979) Geological environments of coalification of the Zacler Beds in the Lower Silesian Coal Basin. Geologia Sudetica 14:103-139

Kwiecińska B (1967) Coked coals from the Wałbrzych Basin. Prace Mineralogiczne 9, PAN, Kraków, 1-81 pp. (in Polish with English summary)

Lorenz S, Mroczkowski J (1978) The sedimentation and petrography of Zechstein and lowermost Triassic deposits in the vicinity of Kochanów (Intra-Sudetic Trough). Geologia Sudetica 13(2):23-39

Malkovský M (1987) The Mesozoic and Tertiary basins of the Bohemian Massif and their evolution. Tectonophysics 137:31-42. https ://doi.org/10.1016/0040-1951(87)90311-8

Maluski H, Rajlich P, Souček J (1995) Pre-Variscan, Variscan and early Alpine thermo-tectonic history of the north-eastern Bohemian massif: an Ar/Ar study. Geol Rundsch 84(2):345-358. https:// doi.org/10.1007/BF00260445

Mastalerz M, Jones JM (1988) Coal rank variation in the IntraSudetic Basin, SW Poland. Int J Coal Geol 10:79-97. https://doi. org/10.1016/0166-5162(88)90006-7

Mastalerz M, Smyth M (1988) Petrography and depositional conditions of the 64/65 coal seam in the Intra-Sudetic Basin, SW Poland. Int J Coal Geol 10:309-336. https://doi.org/10.1016/01665162(88)90008-0

Mastalerz M, Wilks KR (1992) Coal seams of the Wałbrzych Formation, Intra-sudetic Basin, Poland: inferences on changing depositional environment. Int J Coal Geol 20:243-261. https://doi. org/10.1016/0166-5162(92)90016-P

Mazur S, Aleksandrowski P, Turniak K, Awdankiewicz M (2007) Geology, tectonic evolution and Late Palaeozoic magmatism of Sudetes-an overview. In: Kozłowski A, Wiszniewska J (eds) Granitoids in Poland, vol 1. AM Monograph, Warsaw, Poland, pp 59-87

Migoń P, Danišík M (2012) Erosional history of the Karkonosze Granite Massif - constraints from adjacent sedimentary basins and thermochronology. Geol Q 56(3):440-454. https://doi. org/10.7306/gq.1032
Migoń P, Lidmar-Bergström K (2001) Weathering mantles and their significance for geomorphological evolution of central and northern Europe since the Mesozoic. Earth Sci Rev 56:285-324. https ://doi.org/10.1016/S0012-8252(01)00068-X

Milewicz J (1997) Upper Cretaceous of the North Sudetic Depression (litho- and biostratigraphy, paleogeography, tectonics and remarks on raw materials). Prace Geologiczno-Mineralogiczne 61:1-59

Nowak GJ (1993) Lithotype variation and petrography of coal seams from Zacler Formation (Westphalian) in the Intrasudetic Basin, southwestern Poland. Org Geochem 20:295-313. https://doi. org/10.1016/0146-6380(93)90046-E

Nowak GJ (1996) Petrological coal seam accumulation model for the Zacler Formation of the Lower Silesian coal basin, southwestern Poland. In: Gayer R, Harris I (eds) Geological Society, London, Special Publications 109:261-286, https://doi.org/10.1144/GSL. SP.1996.109.01.20

Opluštil S, Cleal CJ (2007) A comparative analysis of some Late Carboniferous basins of Variscan Europe. Geol Mag 144(3):417-448. https://doi.org/10.1017/S0016756807003330

Opluštil S, Schmitz M, Kachlík V, Štamberg S (2016) Re-assessment of lithostratigraphy, biostratigraphy, and volcanic activity of the Late Paleozoic Intra-Sudetic, Krkonoše-Piedmont and Mnichovo Hradiště basins (Czech Republic) based on new U-Pb CA-IDTIMS ages. Bull Geosci 91(2):399-432

Otto V (2003) Inversion-related features along the southeastern margin of the North German Basin (Elbe Fault System). Tectonophysics 373(1-4):107-123. https://doi.org/10.1016/S0040-1951(03)00287 $-7$

Porębski SJ (1981) Świebodzice succession (Upper Devonian-lowest Carboniferous, Western Sudetes): a prograding, mass-flow dominated fan-delta complex. Geologia Sudetica 16:101-192

Sawicki L (1995) Geological map of Lower Silesia with adjacent Czech and German territories (without Quaternary deposits) 1:100,000. Państwowy Instytut Geologiczny, Warszawa

Scheck M, Bayer U, Otto V, Lamarche J, Banka D, Pharaoh T (2002) The Elbe Fault System in North Central Europe-a basement controlled zone of crustal weakness. Tectonophysics 360(1):281-299. https://doi.org/10.1016/S0040-1951(02)00357-8

Scupin H (1936) Zur palaeographie des Sudetischen Kreidemeeres. Zeitschrift der Deutschen Gesellschaft für Geowissenschaften 88:309-325

Senglaub Y, Brix MR, Adriasola AC, Littke R (2005) New information on the thermal history of the southwestern Lower Saxony Basin, northern Germany, based on fission track analysis. Int J Earth Sci 94(5-6):876-896. https://doi.org/10.1007/s00531-005-0008-z

Skoček V, Valečka J (1983) Palaeogeography of the Late Cretaceous Quadersandstein of central Europe. Palaeogeogr Palaeoclimatol Palaeoecol 44:71-92. https://doi.org/10.1016/00310182(83)90005-6

Sobczyk A, Danišík M, Aleksandrowski P, Anczkiewicz A (2015) Post-Variscan cooling history of the central Western Sudetes (NE Bohemian Massif, Poland) constrained by apatite fission-track and zircon (U-Th)/He thermochronology. Tectonophysics 649:47-57. https://doi.org/10.1016/j.tecto.2015.02.021

Sweeney JJ, Burnham AK (1990) Evaluation of a model of vitrinite reflectance based on chemical kinetics. AAPG Bull 74:1559-1570

Teichmüller R, Teichmüller M (1986) Relations between coalification and paleogeothermics in Variscan and Alpidic foredeeps of Western Europe. In: Buntebarth G, Stegena L (eds) Paleogeothermics: Lecture notes in Earth Sciences 5. Springer-Verlag, New York, pp 53-78

Teisseyre AK (1968) The Lower Carboniferous of the Intra-Sudetic Basin; Sedimentary petrology and basin analysis. Geologia Sudetica 4:221-298 
Teisseyre AK (1975) Sedimentology and Paleogeography of the Kulm alluvial fans in the western Intra-Sudetic Basin (Central Sudetes, SW Poland). Geologia Sudetica 9(2):7-135

Thomson SN, Zeh A (2000) Fission-track thermochronology of the Ruhla Crystalline Complex: new constraints on the post-Variscan thermal evolution of the NW Saxo-Bohemian Massif. Tectonophysics 324:17-35. https://doi.org/10.1016/S0040-1951(00)00113 $-\mathrm{X}$

Turnau E, Żelaźniewicz A, Franke W (2005) Middle to early late Viséan onset of late orogenic sedimentation in the Intra-Sudetic Basin, West Sudetes: miospore evidence and tectonic implication. Geologia Sudetica 34:9-16

Uličný D (2001) Depositional systems and sequence stratigraphy of coarse-grained deltas in a shallow-marine, strike-slip setting: the Bohemian Cretaceous Basin, Czech Republic. Sedimentology 48:599-628. https://doi.org/10.1046/j.1365-3091.2001.00381.x

Uličný D, Špičáková L, Grygar R, Svobodová M, Čech S, Laurin J (2009) Palaeodrainage systems at the basal unconformity of the Bohemian Cretaceous Basin: roles of inherited fault systems and basement lithology during the onset of basin filling. Bull Geosci 84(4):577-610

Ulrych J, Fediuk F, Lang M, Martinec P (2004) Late Paleozoic volcanic rocks of the Intra-Sudetic Basin, Bohemian Massif: petrological and geochemical characteristics. Chemie der Erde-Geochemistry 64(2):127-153. https://doi.org/10.1016/j.chemer.2003.11.002

Ulrych J, Pešek J, Štěpánková-Svobodova J, Bosák P, Lloyd FE, von Seckendorff V, Lang M, Novák JK (2006) Permo-Carboniferous volcanism in late Variscan continental basins of the Bohemian Massif (Czech Republic): geochemical characteristic. Chemie der Erde-Geochemistry 66(1):37-56. https://doi.org/10.1016/j. chemer.2004.02.001

Ulrych J, Dostal J, Adamovič J, Jelínek E, Špaček P, Hegner E, Balogh K (2011) Recurrent Cenozoic volcanic activity in the Bohemian Massif (Czech Republic). Lithos 123(1):133-144. https://doi. org/10.1016/j.lithos.2010.12.008

Vamvaka A, Siebel W, Chen F, Rohrmuller J (2014) Apatite fissiontrack dating and low-temperature history of the Bavarian Forest (southern Bohemian Massif). Int J Earth Sci 103:103-119. https ://doi.org/10.1007/s00531-013-0945-x

Ventura B, Lisker F (2003) Long-term landscape evolution of the northeastern margin of the Bohemian Massif: apatite fission-track data from the Erzgebirge (Germany). Int J Earth Sci 92:691-700. https://doi.org/10.1007/s00531-003-0344-9

Ventura B, Lisker F, Kopp J (2009) Thermal and denudation history of the Lusatian Block (NE Bohemian Massif, Germany) as indicated by apatite fission-track data. In: Lisker, F, Ventura B, Glasmacher UA (ed.) Thermochronological methods: from Palaeotemperature constraints to landscape evolution models. Geological Society, London, Special Publications 324:181-192, https://doi. org/10.1144/SP324.14

Wagner GA, Coyle DA, Duyster J, Henjes-Kunst F, Peterek A, Schröder B, Stöckhert B, Wemmer K, Zulauf G, Ahrendt H, Bischoff R, Hejl E, Jacobs J, Menzel D, van den Haute P, Vercoutere C, Welzel B (1997) Post-Variscan thermal and tectonic evolution of the KTB site and its surroundings. J Geophys Res 102:18221-18231. https://doi.org/10.1029/96JB02565

Wojewoda J, Rauch M, Kowalski A (2016) Synsedimentary seismotectonic features in Triassic and Cretaceous sediments of the Intrasudetic Basin (U Devìti Krížù locality)—regional implications. Geol Q 60(2):355-364. https://doi.org/10.7306/gq.1279

Wolff R, Dunkl I, Lange J-M, Tonk C, Voigt T, Eynatten H (2015) Superposition of burial and hydrothermal events: post-Variscan thermal evolution of the Erzgebirge, Germany. Terra Nova 27:292-299. https://doi.org/10.1111/ter.12159

Żakowa H (1963) Stratigraphy-and facial extents of the lower Carboniferous in·the Sudetes. Kwartalnik Geologiczny 7(1):73-94 [in Polish with English summary]

Ziegler PA (1987) Late Cretaceous and Cenozoic intraplate compressional deformations in the Alpine foreland. Tectonophysics 137:389-420. https://doi.org/10.1016/0040-1951(87)90330-1

Ziegler PA, Dèzes P (2007) Cenozoic uplift of Variscan Massifs in the Alpine foreland: Timing and controlling mechanisms. Global Planet Change 58:237-269. https://doi.org/10.1016/j.glopl acha.2006.12.004

Ziegler PA, Bertotti G, Cloetingh SAPL (2002) Dynamic processes controlling foreland development: the role of mechanical (de) coupling of orogenic wedges and forelands. In: Bertotti G, Schulmann $\mathrm{K}$, Cloetingh SAPL (eds) Continental Collision and the tectonosedimentary evolution of forelands. Stephan Mueller Special Publication Series, 1:17-56 